Vol 3. No. 2 Agustus 2019

ISSN 2580-5029

\title{
ANALISIS KARIOMETRIC AKIBAT PEMBERIAN VARIASI DOSIS ASPARTAM PADA PERKEMBANGAN FETUS MENCIT (MUS
}

\section{musculus L.)}

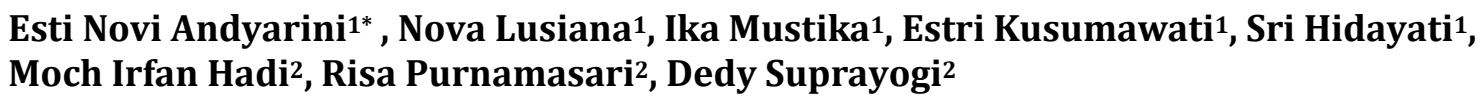

1Fakultas Psikologi dan Kesehatan UIN Sunan Ampel Surabaya, Indonesia

${ }^{2}$ Fakultas Sains dan Tekhnologi UIN Sunan Ampel Surabaya, Indonesia

* esti.novi@uinsby.ac.id

\begin{abstract}
Aspartame is safe for consumption according to the prescribed ADI Acceptable Daily Intake, but this artificial sweetener is not nutritions or does not contain calories so it is not recommended to be consumed during pregnancy. This study was to analyze cariometric effect of aspartame doses in the development of fetal mice (Mus musculus L.). This Study was experimental laboratory research on 24 pregnant mice with 4 treatment groups, control, aspartame dose $13 \mathrm{mg} / \mathrm{Kg} \mathrm{BB}, 39 \mathrm{mg} / \mathrm{Kg} \mathrm{BB}$ and $78 \mathrm{mg} / \mathrm{Kg} B B$ Data was analyzed using SPSS 16 with one way ANOVA. Based on the results of the study there were changes in the number and weight of the fetus due to aspartame doses, there was no change in fetal length due of aspartame dose variations. Consumption of aspartame during pregnancy should be avoided because it can cause teratogenic effects. For further research, it is necessary to observe the morphology and histology of the fetus which is expressed by aspartame to determine the types of congenital abnormalities.
\end{abstract}

Keywords: Aspartame, Amount of Fetus, Fetal Weight, Length of Fetus

\section{ABSTRAK}

Aspartam aman dikonsumsi sesuai dengan ADI yang telah ditetapkan, namun pemanis buatan ini tidak bernutrisi atau tidak mengandung kalori sehingga tidak dianjurkan untuk dikonsumsi selama masa kehamilan. Tujuan penelitian adalah menganalisis kariometri akibat pemberian dosis aspartam pada perkembangan fetus mencit (Mus muculus L.). Jenis penelitian yang digunakan adalah eksperimen pada mencit bunting 24 ekor dengan 4 kelompok perlakuan yaitu kelompok kontrol, dosis aspartam $13 \mathrm{mg} / \mathrm{Kg} \mathrm{BB}, 39 \mathrm{mg} / \mathrm{Kg}$ BB dan $78 \mathrm{mg} / \mathrm{Kg}$ BB. Data dianalisa menggunakan SPSS 16 dengan one way ANOVA. Berdasarkan hasil penelitian terdapat perubahan jumlah dan berat fetus akibat pemberian dosis aspartam, tidak terdapat perubahan panjang fetus akibat pemberian variasi dosis aspartam. Konsumsi aspartam selama kehamilan sebaiknya dihindari penggunaannya karena dapat menyebabkan gangguan pada fetus teratogen. Untuk penelitian selanjutnya perlu dilakukan pengamatan morfologi dan histologi pada fetus yang di papar aspartam untuk mengetahui jenis kelainan kongenital.

Kata Kunci: Aspartam, Jumlah Fetus, Berat fetus, Panjang Fetus 


\section{PENDAHULUAN}

Aspartam merupakan salah satu pemanis buatan sintesis yang memiliki tingkat manis 180-200 kali lebih manis dari sukrosa, dengan nilai kalori yang rendah yaitu $0,4 \mathrm{kkal} / \mathrm{g}$. Aspartam merupakan pemanis sintesis non karbohidrat, asparyl-phenylalaninelmethyl ester, merupakan bentuk metil ester dari dipeptida dua asam amino yaitu asam aspartat dan asam fenilalanin. (Revivo, 2014) (Pratama et al., 2014)

Aspartam digunakan lebih dari 6000 produk sebagai pengganti gula pada berbagai pangan olahan baik makanan maupun minuman, terutama pada minuman ringan, makanan pencuci mulut, permen karet, permen, yoghurt, produk pengontrol berat badan dan sebagai table top sweetener-(F Bararah, 2008).

Sesuai dengan peraturan FDA (Food Drug Administration), aspartam dapat dikonsumsi tidak melebihi dari nilai ADI (Acceptable Daily Intake) yaitu $50 \mathrm{mg} / \mathrm{kg}$ berat badan. Selama proses metabolisme di dalam tubuh, aspartam dipecah menjadi fenilalanin (50\%), asam aspartat (40\%) dan metanol (10\%). Kelebihan fenilalanin dalam tubuh menghalangi pengangkutan asam amino penting ke otak yang berkontribusi pada penurunan kadar dopamin dan serotonin. Asam aspartat pada konsentrasi tinggi bersifat toxic yang menyebabkan hipereksitabilitas neuron dan juga merupakan prekursor asam amino glutamat. Kelebihan aspartam menyebabkan kuantitas dan kurangnya serapan astrocytic sehingga menginduksi eksitotoksisitas dan mengarah pada degenerasi astrocytes dan neuron. Metabolit metanol menyebabkan depresi sistem saraf pusat, gangguan penglihatan, dan gejala lain yang pada akhirnya menyebabkan asidosis metabolik dan koma-(BPOM, 2014).

Pada percobaan lain yang dilakukan pada tikus telah menunjukkan bahwa aspartam merupakan agen karsinogenik di beberapa situs dan efeknya meningkat ketika paparan dimulai sejak kehidupan prenatal/masa kehamilan (Soffritti, 2010).

Sejumlah penelitian menunjukkan bahwa konsumsi aspartam dapat mempengaruhi kadar aspartat dan fenilalanin dalam plasma darah. Fenilalanin tersebut akan berbahaya bagi penderita PKU (phenilketonuria)/fenilketonuria, yang merupakan penyakit genetik sejak lahir dimana tubuh penderita tidak dapat memetabolisme asam amino fenilalanin 
dengan baik dan efektif. Akibatnya, terjadi akumulasi fenilalanin dalam tubuh hingga kadar yang dapat membahayakan dan apabila tidak diangani dengan tepat dapat menyebabkan kerusakan otak dan cacat mental atau keterbelakangan mental penderitanya. (Yusdinar Yusuf and Fatimah Nismah, 2013).

Pada dasarnya aspartam aman dikonsumsi sesuai dengan ADI yang telah ditetapkan. Namun pemanis buatan ini tidak bernutrisi atau tidak mengandung kalori sehingga tidak dianjurkan untuk dikonsumsi selama masa kehamilan. Kebutuhan nutrisi selama masa kehamilan adalah yang mengandung gizi seimbang. Hasil penelitian menurut siapa? menunjukkan dampak penggunaan pemanis buatan dapat menyebabkan migrain dan sakit kepala, bingung, insomnia, iritasi, asma, hipertensi, diare, sakit perut, alergi, kehilangan daya ingat, impotensi dan gangguan seksual, kebotakan, tumor bersifat karsinogenik seperti kanker otak dan kanker kantung kemih.(R Silalahi, 2011)

Hasil penelitian Pratama dkk (2017), sakarin memberi pengaruh nyata terhadap berat badan fetus tikus putih, sehingga perlu dilakukan penelitian apakah aspartam juga memberi pengaruh nyata terhadap kariometri fetus mencit
Tujuan

penelitian adalah menganalisis kariometri pada perkembangan fetus mencit (Mus muculus L.) dengan menggunakan dosis $13 \mathrm{mg} / \mathrm{Kg}$ BB, 39 mg/Kg BB dan 78 mg/Kg BB

\section{METODE}

Jenis penelitian yang digunakan adalah penelitian eksperimental. Dalam penelitian ini pemberian variasi dosis aspartam diharapkan dapat berpengaruh terhadap kejadian kelainan kongenital.

Penelitian ini dilakukan di laboratorium terintegrasi UIN Sunan Ampel Surabaya. Penelitian ini dilaksanakan pada bulan Juli - Oktober 2018.

Dalam penelitian ini mencit bunting merupakan sampel yg homogen. Mencit yang digunakan untuk penelitian ini adalah Mencit Balb C betina dengan berat 20 - 30 gram. Jumlah mencit yang digunakan adalah 24 ekor, dimana setiap kelompok terdiri dari 6 ekor. kelompok 1 (P1) diberi aquades, kelompok 2 (P2) diberi perlakuan aspartame dosis 13 $\mathrm{mg} / \mathrm{Kg}$ BB, kelompok 3 (P3) diberi perlakuan aspartame dosis $39 \mathrm{mg} / \mathrm{Kg} \mathrm{BB}$ dan kelompok 4 (P4) diberi perlakuan aspartame dosis $78 \mathrm{mg} / \mathrm{Kg} \mathrm{BB}$.

Pemberian aspartam secara oral menggunakan jarum sonde diberikan pada usia kebuntingan 1- 15 hari, dengan variasi konsentrasi aspartam. 
Pembedahan mencit dilakukan pada saat hari ke-16 masa kebuntingan mencit

Fetus hidup ditandai dengan adanya gerakan fetus apabila dilakukan stimulasi berupa sentuhan. Jumlah fetus hidup diamati per induk. Pengamatan kelainan meliputi : pengamatan pada kelainan eksternal

Analisis data menggunakan program komputer dengan derajat kepercayaan 95\%. Analisis bivariat menggunakan SPSS dengan $\alpha 0,05$, one way Anova digunakan untuk melakukan analisis multivariat.

\section{HASIL DAN PEMBAHASAN}

Pengamatan berat badan induk mencit (Mus musculus) pada setiap kelompok perlakuan di ukur selama 15 hari masa kebuntingan- Rerata berat badan mencit bunting dapat dilihat pada gambar 1

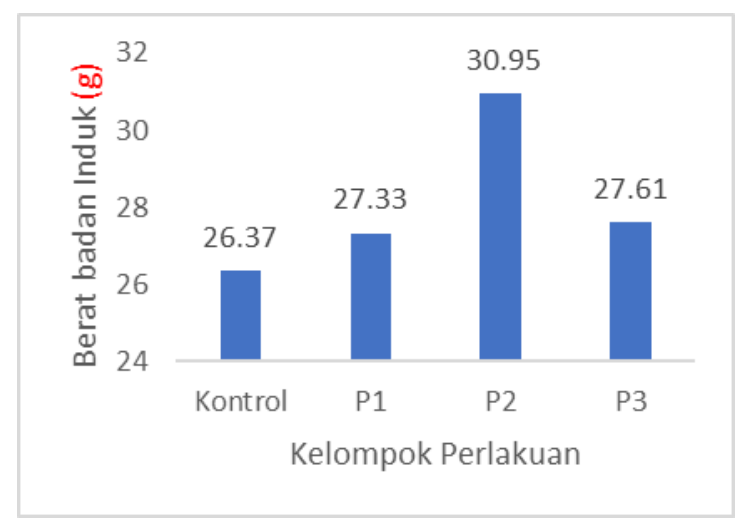

Gambar 1 Rerata Berat Induk Mencit
Berdasarkan gambar 1 Rata-rata berat badan mencit bunting tertinggi pada kelompok P2 atau dosis $39 \mathrm{mg} / \mathrm{Kg} \mathrm{BB}$ yaitu $30,95 \mathrm{mg}$.

Berdasarkan hasil penelitian secara morfologi pengamatan fetus mencit dalam keadaan normal tidak ditemukan adanya eksternal atau cacat kongenital, jumlah fetus pada masingmasing mencit dan kelompok perlakuan dapat dilihat pada tabel 1

Tabel 1 Jumlah Fetus Mencit pada Masing-masing Kelompok Perlakuan

\begin{tabular}{ccccc}
\hline Mencit & Kontrol & P1 & P2 & P3 \\
\hline Mencit 1 & 6 & 7 & 5 & 1 \\
Mencit 2 & 8 & 7 & 6 & 2 \\
Mencit 3 & 10 & 6 & 3 & 9 \\
Mencit 4 & 9 & 7 & 6 & 3 \\
Mencit 5 & 8 & 9 & 9 & 3 \\
Mencit 6 & 8 & 6 & 6 & 6 \\
\hline Jumlah & 49 & 42 & 35 & 24
\end{tabular}

Sumber: Data Primer

Berdasarkan tabel 1 jumlah fetus terbesar pada mencit kelompok kontrol adalah 49 dan jumlah fetus terkecil pada kelompok P3 atau dosis aspartam 78 $\mathrm{mg} / \mathrm{Kg}$ BB yaitu 24, terdapat penurunan jumlah fertus karena perlakuan dapat 
disimpulkan bahwa terdapat perbedaan jumlah fetus mencit antara kelompok kontrol, dan kelompok mencit yang diberi aspartam dosis $13 \mathrm{mg} / \mathrm{Kg} \mathrm{BB}, 39 \mathrm{mg} / \mathrm{Kg}$ BB dan 78 mg/Kg BB. Berdasarkan anova, nilai signifikansi $p$ value $(0,011)$ yang kurang dari $\alpha(0,05)$ artinya terdapat perbedaan dari 4 kelompok (Kontrol, P1, P2 dan P3).

Berdasarkan hasil penelitian jumlah fetus menurun dengan meningkatnya dosis aspartam yang diberikan. Aspartam merupakan pemanis buatan yang sering ditambahkan ke dalam minuman yang banyak dijual di pasaran. Aspartam memiliki rasa manis 200 kali sukrosa, berbentuk tepung kristal berwarna putih dan tidak berbau. Kandungan yang terdapat di dalam aspartam yaitu asam aspartat, fenilalanin dan metanol. KTeratogenesis merupakan proses yang mencakup gangguan perkembangan embrio atau janin dalam uterus mengakibatkan terjadinya kelainan makroskopik atau mikroskopik, perubahan struktural dan fungsional. efek yang ditimbulkan dapat berupa kematian, cacat bawaan, gangguan fungsional dan perlambatan pertumbuhan. (Donatus, 2005). Pada penelitian ini teratogenik yang ditemukan adalah semakin menurun jumlah fetus pada dosis aspartam yang semakin besar artinya dapat terjadi kematian fetus pada fase embryogenesis setelah pemberian variasi dosis aspartam

Penelitian ini sejalan dengan penelitian yang dilakukan oleh Portela dkk (2007) dimana pada mencit bunting yang terpapar aspartam diketahui mengalami pengurangan rata-rata berat plasenta dan janin, panjang tali pusat, dan sebagian besar ukuran kariometri pada nuklei hepatosit janin setelah pemberian aspartam yang diencerkan dengan air pada suhu 40 C. Penggunaan aspartam selama kehamilan bisa menjadi penyebab gangguan pada janin (Portela 2007 dkk).

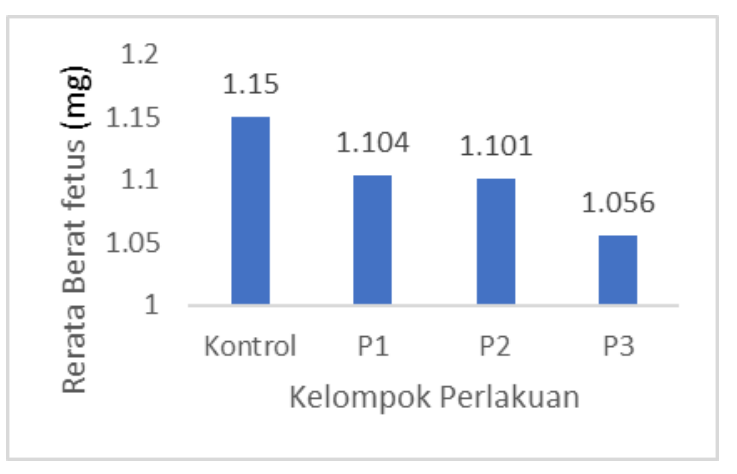

Gambar 2 Rerata Berat BadanFetus

Rata-rata berat badan fetus pada kelompok kontrol adalah 1,15 mg dan berat badan fetus pada kelompok P3 atau dosis $78 \mathrm{mg} / \mathrm{Kg}$ BB adalah 1,056 mg. Berdasarkan uji statistik nilai signifikansi $p$ value $(0,034)$ yang kurang dari $\alpha(0,05)$ artinya terdapat perbedaan dari 4 kelompok (Kontrol, P1, P2 dan P3). 
Dari data hasil penelitian yang telah dilakukan, dapat diketahui bahwa berat badan mencit terbilang tidak stabil. Rata-rata berat badan fetus pada kelompok kontrol adalah 1,15 mg dan berat badan fetus pada kelompok P3 atau dosis $78 \mathrm{mg} / \mathrm{Kg}$ BB adalah 1,056 mg. Tidak stabilnya berat badan pada mencit tersebut karena aspartam juga mengakibatkan peningkatan hormon norepinefrin dimana hormon tersebut mempengaruhi tingkat stress. Stress yang meningkat, mengakibatkan penambahan berat bedan mencit lebih kecil dibandingkan kelompok kontrol. Hal ini dibuktikan dengan perbedaan selisih rerata berat badan tikus sebelum dan sesudah penelitian.(Sari dkk., 2014).

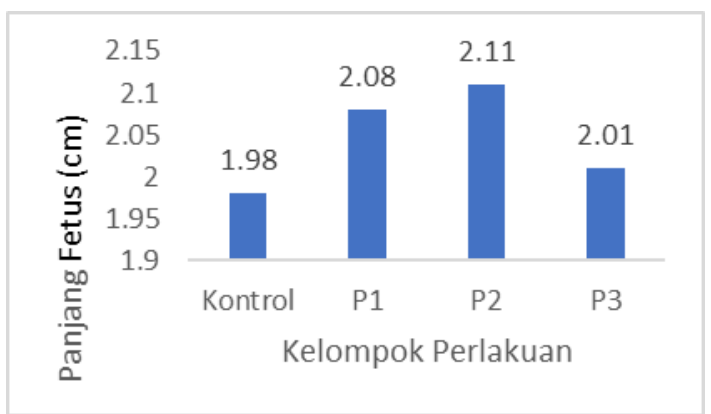

Gambar 3 Rerata Panjang Fetus

Rata-rata panjang fetus mencit setelah pemberian beberapa dosis aspartam adalah 1,98 cm - 2,11 cm. Tidak terdapat perbedaan panjang fetus mencit antara kelompok kontrol, dan kelompok mencit yang diberi aspartam dosis 13 $\mathrm{mg} / \mathrm{Kg} \mathrm{BB}, 39 \mathrm{mg} / \mathrm{Kg}$ BB dan 78 mg/Kg
BB. Hal ini hal ini dapat dilihat dari nilai signifikansi $\mathrm{p}$ value $(0,173)$ yang lebih dari $\alpha(0,05)$ artinya tidak terdapat perbedaan dari 4 kelompok (Kontrol, P1, P2 dan P3)

Kelainan kongenital merupakan kelainan dalam pertumbuhan struktur embrio yang timbul sejak kehidupan hasil konsepsi sel telur. Kelainan anggota dapat menyebabkan terjadinya abortus, lahir mati atau kematian segera setelah lahir.(Ratnaningrum dkk., 2013)

Kelainan pada fetus dapat diakibatkan oleh kesalahan genetika maupun bahan teratogen selama kehamilan yang di dalamnya terdapat proses pembentukan organ atau organogenesis. Zat teratogen dapat mengakibatkan spectrum malformasi ganda (mutipel) dari periode kritis masing-masing organ terutama pada tikus yang memiliki usia kehamilan pendek. Pada tikus memiliki usia kehamilan 22 hari, sementara waktu organogenesis yang dimiliki antara hari ke-8 sampai hari ke-16. Apabila pada hari-hari tersebut terpapar zat teratogen maka janin akan mengalami kelainan. Misalnya tikus terpapar oleh sinar $\mathrm{X}$ ataupun pencemaran logam berat pada hari ke 8 - 12 kehamilan maka akan mengalami cacat mata terutama pada hari 
ke 10, maka $35 \%$ janin mengalami cacat mata dan otak kemudian diikuti cacat jantung, skeletal, dan urogenital. Jika terpapar pada hari ke 9 hingga 15, persentase tertinggi yakni pada hari ke 9 janin mengalami cacat jantung dan rangka tubuh yakni $20 \%$.

Paparan zat teratogen ada hari 8 13 kehamilan juga berpengaruh pada otak janin dan anggota tubuh, persentase tertinggi pada kecacatan otak yakni pada hari ke 10 dan 11 kehamilan sebanyak $30 \%$ sementara kecacatan pada anggota tubuh paling tinggi pada hari ke 11 sebanyak $45 \%$. Zat teratogen ternyata sangat berpengaruh pada akhir waktu organogenesis tikus, antarahari ke 10 hingga 16, mencapai 20\% kecacatan bagian palatum juga dapat terjadi pada hari ke 12 dan 13 sementara hari ke 15 dan 16 terjadi kecacatan urogenital mencapai 20\%. Hal ini dapat terjadi karena adanya kematian sel, keterlambatan pertumbuhan, pembentukan kanker bawaan, maupun gangguan ekspresi protein dan fisiologi tubuh akibat terpaapar zat teratogen seperti sinar X dan logam berat.

Pada penelitian lain yaitu pemberian aspartame dengan dosis 14 $\mathrm{mg} / \mathrm{kg}$ BB pada mencit bunting hari ke 9, 10 dan 11, hasil dari analisis kariometri dan data yang dari morfometri menunjukkan terjadinya perubahan yang lebih sering dan signifikan secara statistik pada sel eksokrin pankreas dari kelompok yang diberi perlakuan dengan larutan aspartam yang dipanaskan sampai $40^{\circ} \mathrm{C}$. Perubahan jarang terjadi diamati pada kelompok yang diberi perlakuan dengan larutan aspartam pada suhu kamar. Pemberian aspartam pada suhu kamar menyebabkan berkurangnya berat badan ibu dan berat janin dan plasenta. Analisis morfometri menunjukkan perubahan dalam diameter kecil dari nukleus. Aspartam yang diencerkan dalam air suling pada suhu 40 - C juga menyebabkan penurunan berat badan ibu. Efek lain dari administrasi larutan ini adalah augmentasi berat plasenta dan perubahan diameter, volume luas dan keliling nucleus (Leme, and Azoubel, 2006).

Efek kumulatif yang berasal dari administrasi kronis aspartame menunjukkan bahwa konsumsi dapat menghasilkan akumulasi progresif produk formaldehida, yang dapat menjelaskan efek kronis yang konsumsi aspartame dapat menginduksi pada jaringan yang sensitif, seperti di otak dan hati. Pada tikus, kehamilan berlangsung dua puluh satu hari dan embriogenesis dimulai pada hari kedelapan hingga hari keempat belas. Selama fase ini paparan 
agen teratogenik dapat memprovokasi secara khusus malformasi organ yang beragam dalam perkembangan. Ketika aspartam diberikan pada hari kehamilan 9, 10 dan 11, yang bertepatan dengan periode teratogenik. Hasil yang didapatkan menunjukkan bahwa aspartam menyebabkan kerusakan pada janin tikus (Portela et al., 2007).

Berdasarkan beberapa penelitian yang telah dilakukan banyak menyebutkan bahwa pengkonsumsian aspartam menyebabkan toksik pada beberapa jaringan dan organ seluler, contohnya pada otak, jika aspartam dikonsumsi pada masa kehamilan maka dapat menimbulkan kerusakan sel astrosit dan neuron, sehingga dapat dimungkinan ketika dilakukan pemeriksaan kariometri pada fetus maka akan didapatkan kecacatan pada bagian cranial, contohnya mikrocephali (penyusutan jaringan otak) hingga anencephaly (sama sekali tidak terbentuk jaringan otak.

Penelitian yang dilakukan oleh ritonga dan suryani (2017) yang meneliti tentang pengaruh minuman berenergi yang mengandung aspartam terhadap gambaran histopatologi cerebelum tikus menunjukkan bahwa minuman berenergi yang mengandung aspartam dapat menyebabkan penurunan kepadatan sel purkinje cerebellum dan sel purkinje patologis pada kelompok perlakuan (Ritonga dan Suryani, 2017).

Penelitian lain juga menunjukkan bahwa penggunaan aspartam dapat mempengaruhi peningkatan stress oksidatif pada otak. Kinerja otak yang terganggu cenderung melibatkan peningkatan stress oksidatif serta penurunan ketersediaan glukosa otak (Abdel Salam, 2012) .

Aspartam ditemukan memiliki hubungan dengan perkembangan banyak gangguan klinis termasuk hepatotoksisitas, nefrotoksisitas, ketidakseimbangan neurotransmitter, dan kelainan kognitif. Fenilalanin tingkat tinggi terjadi pada penderita fenilketonuria (PKU). Pada penderita ini mengalami gangguan dalam merubah fenilalanin menjadi tirosin. Jadi pada penderita PKU tidak boleh mengkonsumsi aspartam. Aspartam bisa menjadi penyebab perubahan perilaku termasuk perilaku impulsif, kurangnya kesabaran, penurunan aktivitas dan koordinasi neuromuskular (Tabasum, 2017).

Pada hewan coba yang terpapar aspartam diketahui mengalami 
peningkatan tingkat peroksida lipid, superoksida aktivitas dismutase (SOD),

\section{DAFTAR PUSTAKA}

tingkat glutathione peroxidase (GPx) dan aktivitas katalase (CAT) sehingga menyebabkan adanya stress oksidatif di daerah otak (Ashok 2015).

\section{KESIMPULAN}

Berdasarkan analisis kariometic fetus mencit (Mus musculus L) yang di beri pelakuan aspartam dosis $13 \mathrm{mg} / \mathrm{Kg}$ BB, $39 \mathrm{mg} / \mathrm{Kg}$ BB dan $78 \mathrm{mg} / \mathrm{Kg}$ BB dapat disimpulkan sebagai berikut

1. Terdapat perbedaan jumlah fetus pada setiap kelompok perlakuan yang diberi aspartam

2. Terdapat perbedaan berat fetus pada setiap kelompok perlakuan yang diberi aspartam

3. Tidak terdapat perbedaan panjang fetus pada setiap kelompok perlakuan yang diberi aspartam

Berdasarkan hasil penelitian, konsumsi aspartam selama kehamilan dapat menyebabkan teratogen walaupun hanya pada jumlah dan berat fetus mencit, sehingga apabila tidak diperlukan sebaiknya penggunaan dihindari. Untuk penelitian selanjutnya perlu dilakukan pengamatan morfologi dan histologi pada fetus yang di papar teratogen aspartam untuk mengetahui jenis kelainan kongenital.

Abdel Salam OME, 2012. Studies on The Effects of Aspartame on Memory and Oxidative Stress in Brain of Mice. Eur. Rev. Med. Pharmacol. Sci. 2012.

BPOM, 2014. Peraturan Kepala Badan Pengawas Obat Dan Makanan Republik Indonesia Nomor 4 Tahun $2014 \quad$ Tentang Batas Maksimum Penggunaan Bahan Tambahan Pangan Pemanis.

Donatus, 2005. Uji Aktivitas Vitamin A terhadap Efek Teratogen Warfarin Pada fetus Mencit Putih. USU Press Medan.

F Bararah, 2008. Studi Paparan Dan Metabolit Sakarin (Pemanis Buatan) Pada Jajanan Anak-Anak. (Skripsii). MIPA Universitas Indonesia, Depok.

Leme, L F A G, Azoubel R, 2006. Effects of Aspartam on The Exocrine Pancreasof Rat Fetus. Int J Morphol 24, 679-684.

Portela, Gabriela Soares, Reinaldo Azoubel, Fernando Batigália, 2007. Effects of Aspartame on MaternalFetal and Placental Weights, Length of Umbilical Cord and Fetal Liver: A Kariometric Experimental Study. Int J Morphol 25, 549-554.

Pratama, R.R., Yerizel, E., Rahmatini, R., 2014. Pengaruh Pemberian Aspartam terhadap Kadar LowDensity Lipoprotein dan HighDensity Lipoprotein pada Tikus Wistar Diabetes Melitus Diinduksi Aloksan. J. Kesehat. Andalas 3. 
R Silalahi, 2011. Bahan Tambahan Makanan (BTM). Universitas Sumatera Utara.

Ratnaningrum, Safriana Dewi, Indriati Dwi Rahayu, 2013. Modul Pembelajaran Kelainan Kongenital. Fakultas Kedokteran Universitas Brawijaya, Malang.

Ritonga AQ, Suryani, 2017. Pengaruh Pemberian Minuman Berenergi yang Mengandung Aspartam terhadap Gambaran Histopatologi Cerebellum Tikus Jantan (Rattus novergicus L.). Ibnu Sina Biomedika 1.

Sari Y, Warnety M, Yohanes A, 2014. Uji Teratogenitas Ekstrak Bungo Timah (Peperomia pellucida L. Kunth.) Terhadap Organ Viseral Embrio Mencit Putih (Mus musculus L.). J. Ilm. Biol. Biog. 2, 115-118.

Soffritti, 2010. Aspartame Administered in Feed, Beginning Prenatally through Life Span, Induce Cancers of the Liver and Lung in Male Swiss Mice 1197-1206.

Yusdinar Yusuf, Fatimah Nismah, 2013. Analisa Pemanis Buatan (Sakarin, Siklamat Dan Aspartam) Secara Kromatografi Lapis Tipis Pada Jamu Gendong Kunyit Asam Di Wilayah Kelapa Dua Wetan Jakarta Timur. Lemlitbang UHAMKA.

Zafar Tabasum, 2017. Aspartame: Effects and Awareness. MOJ Toxicol. 3. 